\title{
Cikkismertetés: Étrendi kockázatok egészséghatása 195 országban, 1990-2017
}

\author{
Article review: Health effects of dietary risks in 195 countries, 1990-2017
}

Ismertető: $\quad$ Erdei Gergő $₫$

Ismertetett cikk: GBD 2017 Diet Collaborators. Health effects of dietary risks in 195 countries, 1990-2017: a systematic analysis for the Global Burden of Disease Study 2017. Lancet. 2019;393: 1958-72. doi: 10.1016/S0140-6736(19)30041-8

Beküldve: $\quad$ 2019. 06. 28.

doi: $\quad$ 10.24365/ef.v60i4.495

Kulcsszavak: étrend; kockázati tényezők; halálozás; megbetegedés; krónikus, nem fertőző megbetegedések

Keywords: diet; risk factors; mortality; morbidity; non-communicable diseases

\section{HÁTTÉR}

Ugyan a helytelen étrend fontos megelőzhető kockázati tényező a nem fertőző betegségek (non-communicable diseases) esetében, az elégtelen tápanyag-bevitel nem fertőző betegségekre gyakorolt hatását eddig még nem értékelték áttekintő tanulmányban. Jelen cikk célja a leggyakrabban fogyasztott élelmiszerek és legfőbb tápanyagok fogyasztásának értékelése 195 országban, valamint felmérni, hogy ezek elégtelen bevitele milyen hatással van a nem fertőző betegségek halálozási gyakoriságának mutatóira. [1. táblázat]

\section{MÓDSZER}

Összehasonlító kockázatértékeléssel becsülték meg a 25 éves vagy annál idősebb felnőttek körében az egyes táplálkozási kockázati tényezők hatását. Az elemzés fő inputja az egyes táplálkozási tényezők bevitele (15 étrendi kockázati tényező), a táplálkozási tényezőknek a betegség végpontjára gyakorolt hatása és a legalacsonyabb halálozási kockázathoz kapcsolódó táplálkozási tényezők bevitele. Az egyes táplálkozási tényezők fogyasztásával kapcsolatos információk a tudományos szakirodalom szisztematikus áttekintéséből, az országos szintű és egyéb reprezentatív táplálkozási felmérések adataiból származtak.

\section{EREDMÉNYEK}

2017-ben 11 millió (95\%-os bizonytalansági intervallum [uncertainty interval] mellett 10-12 millió) halálesetet és 255 millió (234-274 millió) egészségkárosodással korrigált életévet (disability adjusted life years, DALY) tulajdonítottak az étrendi kockázatoknak. A legfőbb táplálkozási kockázati tényezők, valamint a velük összefüggésbe hozható halálesetek száma és DALY: magas nátrium-bevitel (3 millió [1-5 millió] haláleset és 70 millió [34-118 millió] DALY), a teljes kiőrlésű gabonák alacsony bevitele (3 millió [2-4 millió] haláleset és 82 millió [59-109 millió] DALY) és az elégtelen gyümölcsfogyasztás (2 millió [1-4 millió] haláleset és 65 millió [41-92 millió] DALY). 
2017-ben világszerte szinte az összes kedvező táplálkozás-élettani tulajdonsággal bíró élelmiszer fogyasztása elégtelen volt. A legnagyobb különbség a valós és az optimális bevitel között a diófélék és olajos magvak, a tej és a teljes kiőrlésű gabonafélék esetében volt. Ugyanakkor a kedvezőtlen táplálkozás-élettani tulajdonságokkal bíró élelmiszerek (pl. cukorral édesített italok, feldolgozott hús, vörös hús) fogyasztása meghaladta az optimális szintet. Érdemes megjegyezni, hogy a táplálkozási adatok vegyes forrásokból származnak, valamint nem álltak rendelkezésre minden országban, ami növeli a becslések statisztikai bizonytalanságát.

\section{TANULSÁGOK HAZAI SZAKEMBEREK SZÁMÁRA}

Ez az átfogó tanulmány populációs szinten ad képet 15 étrendi kockázatnak a krónikus, nem fertőző betegségek okozta halálozásra és megbetegedésre gyakorolt potenciális hatásáról, kiemelve az étrend javitásának fontosságát. Eredményeik a bizonyítékokon alapuló étrendi beavatkozások végrehajtását szolgálják és platformot biztosítanak az egészségre gyakorolt hatásuk rendszeres időközönként történő értékeléséhez.

1. táblázat: Nem fertőző megbetegedésekre ható étrendi kockázati tényezők

\begin{tabular}{|c|c|c|c|}
\hline & Expozíció meghatározása & $\begin{array}{l}\text { Optimális beviteli } \\
\text { szint (optimális } \\
\text { beviteli tarto- } \\
\text { mány) }\end{array}$ & $\begin{array}{l}\text { Az adatok } \\
\text { reprezentati- } \\
\text { vitási indexe } \\
\text { (\%) }\end{array}$ \\
\hline $\begin{array}{l}\text { Gyümölcsökben } \\
\text { szegény étrend }\end{array}$ & $\begin{array}{l}\text { Gyümölcsök átlagos napi fogyasztása (friss, } \\
\text { fagyasztott, főtt, konzervált vagy szárított } \\
\text { gyümölcsök, kivéve a gyümölcslevek és a sózott } \\
\text { vagy pácolt gyümölcsök) }\end{array}$ & $\begin{array}{c}250 \mathrm{~g}(200-300 \mathrm{~g}) \\
\text { naponta }\end{array}$ & 94,9 \\
\hline $\begin{array}{l}\text { Zöldségekben } \\
\text { szegény étrend }\end{array}$ & $\begin{array}{l}\text { Zöldségek átlagos napi fogyasztása (friss, fagyasz- } \\
\text { tott, főtt, konzervált vagy szárított zöldségek, } \\
\text { kivéve hüvelyesek és sózott vagy pácolt zöldsé- } \\
\text { gek, zöldséglevek, diófélék, magvak és magas } \\
\text { keményítőtartalmú zöldségek, például burgonya } \\
\text { vagy kukorica) }\end{array}$ & $\begin{array}{c}360 \mathrm{~g}(290-430 \mathrm{~g}) \\
\text { naponta }\end{array}$ & 94,9 \\
\hline $\begin{array}{l}\text { Hüvelyesekben } \\
\text { szegény étrend }\end{array}$ & $\begin{array}{l}\text { Hüvelyesek átlagos napi fogyasztása (friss, } \\
\text { fagyasztott, főtt, konzervált vagy szárított } \\
\text { hüvelyesek) }\end{array}$ & $\begin{array}{c}60 \mathrm{~g}(50-70 \mathrm{~g}) \\
\text { naponta }\end{array}$ & 94,9 \\
\hline $\begin{array}{l}\text { Teljes kiőrlésú } \\
\text { gabonákban } \\
\text { szegény étrend }\end{array}$ & $\begin{array}{l}\text { Teljes kiőrlésű gabonák (korpa, csíra és belső } \\
\text { táplálószövet) reggeli gabonapehelyből, kenyér- } \\
\text { ből, rizsből, tésztából, kekszből, muffinból, tortillá- } \\
\text { ból, palacsintából és más forrásokból }\end{array}$ & $\begin{array}{c}125 \mathrm{~g}(100-150 \mathrm{~g}) \\
\text { naponta }\end{array}$ & 94,9 \\
\hline $\begin{array}{l}\text { Olajos magvak- } \\
\text { ban szegény } \\
\text { étrend }\end{array}$ & Diófélék és olajos magvak átlagos napi bevitele & $\begin{array}{l}21 \mathrm{~g}(16-25 \mathrm{~g}) \\
\text { naponta }\end{array}$ & 94,9 \\
\hline
\end{tabular}




\begin{tabular}{|c|c|c|c|}
\hline $\begin{array}{l}\text { Tejben szegény } \\
\text { étrend }\end{array}$ & $\begin{array}{l}\text { Tej átlagos napi fogyasztása, beleértve a zsírmen- } \\
\text { tes, alacsony zsírtartalmú és teljes zsírtartalmú } \\
\text { tejet, a szója és más növényi tej kivételével }\end{array}$ & $\begin{array}{l}435 \mathrm{~g}(350-520 \mathrm{~g}) \\
\text { naponta }\end{array}$ & 94,9 \\
\hline $\begin{array}{l}\text { Vörös húsokban } \\
\text { gazdag étrend }\end{array}$ & $\begin{array}{l}\text { A vörös hús (marhahús, sertés, bárány és kecske } \\
\text { átlagos napi fogyasztása, a baromfi, hal, tojás és } \\
\text { minden feldolgozott hús kivételével) }\end{array}$ & $\begin{array}{l}23 \mathrm{~g}(18-27 \mathrm{~g}) \\
\text { naponta }\end{array}$ & 94,9 \\
\hline $\begin{array}{l}\text { Feldolgozott } \\
\text { húskészítmé- } \\
\text { nyekben gazdag } \\
\text { étrend }\end{array}$ & $\begin{array}{l}\text { Füsttel, sózással vagy kémiai tartósítószerek } \\
\text { hozzáadásával tartósított hús átlagos napi } \\
\text { fogyasztása }\end{array}$ & $\begin{array}{l}2 \mathrm{~g}(0-4 \mathrm{~g}) \\
\text { naponta }\end{array}$ & 36,9 \\
\hline $\begin{array}{l}\text { Cukorral édesí- } \\
\text { tett üdítőitalok- } \\
\text { ban gazdag } \\
\text { étrend }\end{array}$ & $\begin{array}{l}\geq 50 \text { kcal/adagot tartalmazó italok átlagos napi } \\
\text { fogyasztása, beleértve a szénsavas italokat, ener- } \\
\text { giaitalokat, gyümölcsitalokat, de kivéve a 100\%-os } \\
\text { gyümölcs- és zöldségleveket }\end{array}$ & $\begin{array}{l}3 \mathrm{~g}(0-5 \mathrm{~g}) \\
\text { naponta }\end{array}$ & 36,9 \\
\hline $\begin{array}{l}\text { Rostban } \\
\text { szegény étrend }\end{array}$ & $\begin{array}{l}\text { Az összes forrásból származó rostok átlagos napi } \\
\text { bevitele, beleértve a gyümölcsöket, zöldségeket, } \\
\text { gabonákat, hüvelyeseket }\end{array}$ & $\begin{array}{l}24 \mathrm{~g}(19-28 \mathrm{~g}) \\
\text { naponta }\end{array}$ & 94,9 \\
\hline $\begin{array}{l}\text { Kalciumban } \\
\text { szegény étrend }\end{array}$ & $\begin{array}{l}\text { Az összes forrásból származó kalcium átlagos napi } \\
\text { bevitele, beleértve a tejet, a joghurtot és a sajtot }\end{array}$ & $\begin{array}{l}1,25 \mathrm{~g}(1-1,5 \mathrm{~g}) \\
\text { naponta }\end{array}$ & 94,9 \\
\hline $\begin{array}{l}\text { Omega-3 } \\
\text { zsírsavakban } \\
\text { szegény étrend }\end{array}$ & $\begin{array}{l}\text { Az eikozapentaénsav és a dokozahexaénsav } \\
\text { átlagos napi bevitele }\end{array}$ & $\begin{array}{l}250 \text { mg (200-300 } \\
\text { mg) naponta }\end{array}$ & 94,9 \\
\hline $\begin{array}{l}\text { Többszörösen } \\
\text { telítetlen } \\
\text { zsírsavakban } \\
\text { szegény étrend } \\
\end{array}$ & $\begin{array}{l}\text { Az omega- } 6 \text { zsírsavak átlagos forrása, főleg } \\
\text { folyékony növényi olajokból, beleértve a szója-, } \\
\text { kukorica- és sáfrányolajat. }\end{array}$ & $\begin{array}{l}\text { A teljes napi } \\
\text { energia-bevitel } \\
\text { 11\%-a (9-13) }\end{array}$ & 94,9 \\
\hline $\begin{array}{l}\text { Transzzsírsav- } \\
\text { ban gazdag } \\
\text { étrend }\end{array}$ & $\begin{array}{l}\text { Az összes forrásból származó transzzsír átlagos } \\
\text { napi bevitele, főként a részben hidrogénezett } \\
\text { növényi olajok, valamint a kérődzők húsa, teje } \\
\text { és a tejéből készült termékek }\end{array}$ & $\begin{array}{l}\text { A teljes napi } \\
\text { energia-bevitel } \\
0,5 \%-a(0-1 \%)\end{array}$ & 36,9 \\
\hline $\begin{array}{l}\text { Nátriumban } \\
\text { gazdag étrend }\end{array}$ & 24 órás vizelet-nátrium mérése g/nap & $\begin{array}{l}3 \mathrm{~g}(1-5 \mathrm{~g}) \\
\text { naponta }\end{array}$ & 26,2 \\
\hline
\end{tabular}

